\title{
Beyond the Workplace: "Upstream" Business Practices and Labor Standards in the Global Electronics Industry
}

\author{
Richard M. Locke \\ Brown University \\ Providence, Rhode Island \\ Hiram Samel \\ Saïd Business School \\ University of Oxford \\ Oxford, United Kingdom
}

November 2017

\begin{abstract}
Despite decades of debate and efforts to improve global labor standards, multiple problems still persist. Whether arguing for a more active role for the state, persuading firms to adopt codes of conduct, improving monitoring and sanctioning processes or seeking a higher degree of commitment between supply chain actors, scholars still lack an adequate explanation for why labor problems do not show improvement. Existing theories, while they will help, are not sufficient to solve this issue because they are focused on the production side of markets - the result both of an intellectual and policy bias towards production and the tendency to look for solutions where problems occur. Using a case study of Hewlett-Packard's (HP) supply chain, qualitative and quantitative data from field visits to plants in South East Asia and a unique dataset of HP's code of conduct audits, we demonstrate that even under the most-likely conditions that favor previous theories of labor standards, code of conduct violations, in particular excess working hours, exhibit widespread persistence. Having explained this, we demonstrate that this persistence is the product of a set of policies and practices designed and implemented upstream by global buyers and their lead suppliers
\end{abstract}




\section{Introduction}

Notwithstanding years of debate and controversy, and numerous interventions by national regulatory authorities, global brands, and transnational non-governmental organizations to improve labor standards in factories linked to global supply chains, poor working conditions, excessive work hours, precarious employment practices, and low wages persist. Numerous scholars claim that this persistence is due to inadequate government regulation or ineffective (poorly-designed) private compliance systems. As a result, they argue for either the revitalization of state regulatory agencies and enforcement capacities (Piore and Schrank 2008; Seidman 2007) or for improved private monitoring and capability-building initiatives aimed at coaxing firms to address these labor problems (Locke, Amengual, and Mangla 2009; O’Rourke 2003; Weil 2004). More recently, these debates have yielded a hybrid solution where public and private efforts can complement each other leading to better outcomes and new forms of supply chain governance (Locke, Rissing, and Pal 2013). Scholars also argue, however, that this layering of public and private efforts, whether intentional or not, can lead to a 'puzzle of rules' that weakens enforcement and commitment (Bartley 2011; Bartley et al. 2015).

This article argues that these interventions -- no matter how well intentioned and designed and regardless of whether they originate from private actors, public authorities, or both--are insufficient. This is because they focus solely (or primarily) on the locus of production, on the factories producing for global buyers. Although this focus on the workplace makes sense, given that this is where most labor standards violations are 
manifest, the reality is that many of the workplace problems we observe in global supply chains are, in fact, the product of a set of policies and practices designed and implemented upstream by global buyers and their lead suppliers. In other words, in a business environment characterized by dynamic consumer demand, shorter product life cycles, and concentrated retail channels, global brands have reorganized their supply chains in order to optimize efficiencies and minimize financial and reputational risks. Timely delivery of the latest products to the market is essential for global brands competing in these dynamic markets. Labor costs, although important, are often a second order consideration (Jack and Raturi 2002; Minnich and Maier 2007).

As a result, global brands and their lead suppliers have developed production planning and manufacturing systems that minimize the risks of not meeting consumer demand in a timely manner. Although these techniques allow for a broader selection of products, faster product introductions, and reduced inventory of poor-selling products for both brands and large retailers, they also generate various labor problems downstream for factories and their workers. The production architecture necessary to operate this more "lean" system is designed to exhibit very high volatility at the point where products are assembled. As a result, order volatility is met through a Taylorist work organization, where products are assembled by hand, enabling the rapid scaling up and down of production. Such a system requires a very flexible labor supply, often in the form of migrant workers who work long hours at low wages; a situation that chronically leads to persistent labor standards violations, in particular excessive working hours that can run up to 72 or 84 hours per week. 
The findings presented in this article have implications for our understanding of how best to address labor standards issues, especially in industries with short product life cycles, volatile consumer demand and increasing brand concentration. Yet to date there has been very little attention paid to the "upstream" sources of poor working conditions in global supply chains. This is due primarily to the way most labor scholars study and understand these issues. On the one hand, we focus on the workplaces and factories because this is, in fact, where workers are employed and where we observe the vast majority of the violations in labor standards and worker rights. On the other hand, we "look under the lamppost" because of our own intellectual traditions and biases towards production (where people make things) as opposed to how these products are designed, sold and consumed.

Yet shifting patterns of consumption are provoking significant changes in supply chain governance, manufacturing practice, and ultimately, employment conditions for the millions of workers who make the goods each of us consume every day. Some scholars have explored the impact of ethical consumption and various certification schemes on consumer behavior (Bartley et al. 2015; Hainmueller, Hiscox, and Sequeira 2011) and others have analyzed the politics underlying consumer credit and consumer protection in various advanced industrial nations (Trumbull 2011; Trumbull 2006). However, there has been very little systematic examination of how the management practices global brands and large retainers promote in response to upstream industry-level dynamics impact working conditions downstream in the factories making their products. This is the focus of this article. 
Our research is situated in the global electronics industry, a setting where one might expect higher degrees of compliance with labor standards and hence, improved working conditions. The suppliers operating in this industry are for the most part themselves large multinational corporations. Unlike all but the largest suppliers in lower technology sectors such as apparel and footwear, many firms in the electronics industry have significant capital resources and operational capabilities. Benefiting from access to both local and global capital markets, electronics brands and suppliers, as seen in Table 1, have built sizable operations with revenue regularly exceeding $\$ 1$ billion and the largest having revenue in excess of $\$ 10$ billion or more. They are not the typical supplier one imagines existing in the apparel or toy industries of the global South.

----Insert Table 1 about here---------

\section{Improving Labor Standards in Global Supply Chains}

The current era of globalization is characterized by fragmented ownership and the geographic dispersion of production. This economic transformation poses a set of opportunities and challenges for emerging economies. Involvement in global supply chains may generate new work opportunities, technological spillover, or higher wages for local firms and their workers. Yet integration into global production networks can also create a series of labor issues (e.g., poor working conditions, excessive working hours, etc.) at these workplaces. Given the competitive pressures, power asymmetries between buyers and suppliers (Gereffi, Humphrey, and Sturgeon 2005), and a worldwide decline in workplace legal protections (Standing 2007) it is unsurprising that multiple sources 
have documented harsh working conditions in an array of global supply chain factories (Connor and Dent 2006; Good Electronics 2009; Pruett 2005; SwedWatch, SACOM, and SOMO 2008; Verite 2004).

Historically, two distinct accounts seek to explain the persistence of poor working conditions and weak labor standards in global supply chains. Both views believe that these persistent issues cannot be resolved solely by traditional private compliance programs. Where they differ is their focus on what specifically needs to be done to complement these private voluntary initiatives. One view claims that persistent labor violations are the result of inadequate government regulation and thus argues for increased state monitoring and enforcement of labor conditions in factories operating within their national boundaries (Piore and Schrank 2008; Schrank 2006; Seidman 2007; Weil 2004). The second view, while acknowledging the importance of state regulation, also recognizes the continuing difficulties most developing countries face in building up these institutional capacities (Fung et al. 2001; Nadvi and Waltring 2004). Private voluntary regulation, in fact, emerged to fill the regulatory void created by weak or absent government enforcement of national labor laws. According to this second view, the persistence of poor working conditions in global supply chain factories stems from various design and implementation weaknesses in these still necessary (albeit insufficient) private monitoring programs. To remedy these weaknesses, various scholars have proposed that private compliance programs become more transparent (Fung, O’Rourke, Sabel 2001) and/or better coordinated among firms in the same industry (Nadvi and Waltring 2004; O'Rourke 2003), and/or focused on providing suppliers with the capabilities (technical know-how, management systems) needed to run more efficient 
and ethical businesses (Amengual 2014; Locke, Amengual, and Mangla 2009; Locke and Romis 2007).

Previous work on private regulation has examined codes of conduct within athletic footwear (Rosenzweig 1994; Strasser and Becklund 1993), apparel (Rodriguez-Garavito 2005; Weil 2004; Locke, Amengual, and Mangla 2009), and agriculture (Coslovsky and Locke 2013; Riisgaard 2009). These studies of low-technology industries have observed generally poor compliance with international labor and environmental standards and at best modest improvements as a result of private regulatory efforts.

While more recent work has begun to examine the relationship between production systems, capability-building, upgrading and social performance in the apparel industry, the results have also been mixed. Nike has made significant investments in moving longterm suppliers to lean methodologies. While this effort was designed to strengthen management processes and systems, it has also improved labor relations resulting in a higher likelihood of meeting code of conduct compliance (Distelhorst, Hainmueller, and Locke 2016). However, in another study focused on Moroccan fast-fashion suppliers, high levels of worker turnover were linked to the introduction of these new management systems (Rossi 2013). In fact, Rossi found that this particular capability-building intervention helped a core group of employees while simultaneously making employment more precarious for other workers. .

In addition, given the nature of the work being done in global supply chains, scholars have more recently examined whether private systems of regulation can act in isolation, suggesting that a mixture of private and public efforts are necessary to improve outcomes (Amengual 2010; Locke, Qin, and Brause 2007). Private programs are often layered on 
top of public ones, with the result that the two may either complement or alternatively, undermine one another (Bartley 2011; Locke, Rissing, and Pal 2013).

\section{Labor Standards in the Electronics Industry}

Is the global electronics industry different? Electronics suppliers' scale, sophistication and market position should create new dynamics of interaction with global buyers (Gereffi, Humphrey, and Sturgeon 2005). Yet notwithstanding the huge volume of contract manufacturing business, profits remain highly concentrated among the lead firms involved in product definition, marketing, and retail. Fluctuating market demand and shorter product life cycles have produced a volatile manufacturing environment within the electronics sector. Advances in technology have led to the rapid obsolescence of consumer electronics products. In response to variable demand and intense cost pressures, contract manufactures have adopted flexible employment policies. These work relationships are characterized by long work hours, precarious or temporary work, and high concentrations of women and migrant employees.

Contract manufacturers employ significant numbers of contingent or agency workers in order to limit worker benefit coverage and enable suppliers to hire and fire employees rapidly in response to variations in production demand. Many of the migrant workers are also subject to high recruitment fees that they pay to labor agencies that match them with these temporary jobs (CAFOD 2004; Chan and Peyer 2008; Smith, Sonnenfeld, and Fellow 2006). A representative from the electronics supplier Foxconn went as far to say "[Foxconn] believes that it would be better to hire all workers directly; unfortunately our variable manufacturing volumes do not allow us to do it"(Centre for 
Reflection and Action on Labour Issues (CEREAL) 2007). This combination of lowskilled assembly work by large numbers of contingent and/or migrant workers has led to labor rights issues surrounding working hours, benefits, and safety (Duhigg and Bradsher 2012; Kiss 2012; Good Electronics 2009; Smith, Sonnenfeld, and Fellow 2006).

The harsh working conditions in the industry were most vividly manifest by the tragic worker suicides within Chinese electronics facilities owned by Foxconn (Dean and Tsai 2010). These suicides rallied coalitions of investors (Interfaith Center on Corporate Responsibility 2010) and NGOs to condemn abusive workplace conditions in the industry and call for stricter oversight. While the problems in the electronics industry's supply chain are now well-known, only recently have efforts to remediate these issues emerged (Distelhorst et. al. 2015; Locke, Rissing, and Pal 2013; Nadvi and Raj-Reichert 2015. Given the differential nature-scale, scope and resources--of electronics brands and suppliers, why do we see suppliers with billions of dollars in revenue and hundreds of millions in capital repeatedly violate labor standards? What role, if any, do industry dynamics play in setting working conditions? Are some problems, such as excess working hours, a necessary condition for these types of large, highly-dynamic supply chains? This article argues that although more effective regulation and better-designed private compliance systems would certainly help improve labor standards in these global supply chains, they are not in and of themselves sufficient to tackle these persistent workplace issues.

Although the alternative explanations reviewed above may help explain (and provide guidance for improving) working conditions and labor standards in certain sectors and/or nation-states, they appear unable (in and of themselves) to explain why we 
see persistent working hours violations in numerous electronics factories. There must be other forces at work. We argue that the policies and practices implemented upstream in response to highly dynamic consumer and retail markets shape supply chain practices, production architectures, and work organization downstream in the factories manufacturing these goods. Labor standards problems, exemplified by excessive working hours, are not only (or even primarily) the result of poor managerial practices and behavior in the plants, but rather stem from the series of supply-chain responses to these dynamic market conditions that have become routinized and optimized by global buyers in an effort to mitigate their financial and reputation risks and meet demand for their products in a timely manner.

In seeking to minimize uncertainty, firms routinely utilize product design, demand-signaling and production-planning practices that mandate modularity of design and assembly allowing for the building of buffer inventories of lower-cost standardized intermediates while postponing the final assembly of differentiated and much costlier finished goods. Although these practices mitigate risk by producing only those goods demanded by consumers, they create labor problems by structurally constraining the supply chain's downstream production architecture and corresponding design of work organization. In what follows we describe in detail the evolution of these upstream business practices and their consequences for work organization and working conditions in the factories. We finish by suggesting an alternative, complementary approach to addressing them.

\section{Data and Methods}


This article draws upon both a unique dataset of Electronic Industry Citizenship Coalition (EICC) supplier audits that Hewlett-Packard (HP) selectively administered to its network of global suppliers, as well as field interviews with HP suppliers and staff in the United States and Southeast Asia in 2009. Hewlett Packard (HP) is one of the world's largest global electronics firms. ${ }^{i}$ In the fiscal year 2010, when we conducted our research for this study, HP shipped over sixty-four million personal computers (PCs) for a global market share of 20\%. ${ }^{\text {ii }}$ It directly employed over 325,000 people across 170 countries and contracted with approximately 1,000 production suppliers in 1,200 locations worldwide (Hewlett Packard 2011). Although it is difficult to estimate the number of workers employed in its supply chain, HP reports that the ninety suppliers audited in 2010-less than $10 \%$ of all of HP's suppliers - employed over 260,000 workers.

\section{The HP Audits, Pilot Program and Fieldwork}

HP shared over five hundred original audit reports conducted between June 2004 and January 2009 with us. This sample describes 276 unique facilities, 137 of which received multiple audits. These audits assessed supplier compliance with the Electronics Industry Citizenship Coalition (EICC) code of conduct, and were conducted by HP employees explicitly trained to evaluate suppliers' compliance with the EICC code. Audits were performed onsite at supplier facilities and a subsection of audit reports were verified by an external organization to ensure the accuracy of assessments and to enable improvements. Of the 276 facilities in our dataset, only seven complied fully with all requirements included in the EICC code of conduct at the time the HP shared these reports with us. In addition, HP initiated a separate pilot program on working hour 
violations with thirteen plants in China and provided us with monthly detailed reports from January 2008 to November 2009.

This quantitative analysis was complemented by qualitative field research in several countries (China, Mexico, Czech Republic, Hungary, Thailand, Malaysia and Singapore). For this article, we visited seven HP first-tier facilities in Malaysia, Singapore and Thailand in June 2009, conducting 27 interviews with plant managers, human resources managers, production managers, supplier's corporate social responsibility (CSR) managers, regional HP auditors, corporate officers and labor nongovernmental organization (NGO) representatives. All plant interviews were conducted in the absence of HP personnel and lasted between one and three hours. Some plant visits also yielded detailed quantitative data on production, employment, and purchasing practices. Facilities were selected for variation in audit outcomes, product mix, demand volatility, work organization and the institutional setting of the plant's location. Finally, we drew on published papers by members of HP's production planning group.

\section{HP as Critical Case: Benefits and Limitations}

Given its history, position in the industry, capital resources and well-known commitment to social responsibility, we consider Hewlett-Packard to be a most-likely case (Goldthorpe et al. 1969): if any company can improve labor standards along its supply chain, Hewlett-Packard should be able to do so. HP is well known for the 'HP Way' and its commitment to social responsibility (Collins and Packard 2005). It was instrumental in the setting up of the industry's code of conduct and it was HP's own 
employees that pointed out the first labor problems in the industry when HP outsourced its ink-jet production to Asian suppliers from its plants in Vancouver, Washington.

While the use of a single case has a number of limitations, especially concerning the generalizability of our findings, the HP data yields significant within-case variation, including supplier, country location, demand volatility, product scope (mix) and scale (volume). This variation helps us to control for a number of key factors: national institutions--as reflected in regulatory response to labor law violations; brand-supplier contracting - as reflected in the nature of production within individual plants; and supplier capabilities and resources — as reflected in the work organization and capital assets employed. It also provides us with analytical leverage to understand the role industry dynamics may have beyond any individual firm.

The use of HP as a single-case will not allow us to observe other electronics firms' compliance programs. This may give rise to the possibility that our findings are HP specific and thus not generalizable. Given, however, the electronics industry's adoption of the EICC code of conduct as a means to eliminate duplicate audits and related 'audit fatigue' and that almost all electronics firms use the EICC, code and audit protocol, we believe this risk is relatively low. We further believe that the repeated labor problems in electronics factories, reported by scholars, civil society and the media, are further indication that compliance is extremely difficult for all firms and that our findings can help shed light on why this is the case.

Finally, although interviews with HP auditors and CSR managers revealed that HP does periodically terminate relationships with suppliers that repeatedly violate their code of conduct, we did not have access to HP purchasing managers who could verify 
what threshold had to be passed for supplier termination. One limit of our research and almost all work that examines labor standards in large global corporations is that CSR managers and more operational/financial managers operate in siloes, often not coordinating their actions within the firm, let alone to their suppliers.. HP's auditors have a fair amount of discretion but ultimately purchasing decisions are made by the purchasing team and were thus unobserved by us.

\section{Structure of EICC Audits}

In response to poor labor and environmental conditions in the electronics industry, Hewlett Packard (HP) and other lead firms launched corporate social and environmental responsibility (SER) programs in the late 1990s. Moreover, prominent lead firms such as HP, Dell, and IBM were able to initiate a collaborative approach to monitoring supplier conduct through the establishment in 2004 of the Electronics Industry Citizenship Coalition and its code of conduct. Although the code was initially implemented more or less independently by each member of the EICC, member companies have made significant progress over time to coordinate these efforts by moving towards a common pool of auditors and sharing audit results in an effort to reduce audit fatigue among suppliers and eliminate conflicting standards, two issues that often hamper private monitoring efforts (Locke, Qin, and Brause 2007; Nadvi and Waltring 2004; O'Rourke 2003).

The EICC code is divided into seven sections: the first covers broad code of conduct compliance issues, and is followed by six more specific sections addressing issues related to labor, health, environment, labor management, environmental health and 
safety management, and ethics. Each of these sections contains between three and eleven subsections that are assessed for compliance outcomes. If a problematic area is observed it can be flagged as an "observation," "minor violation," or "major violation" depending on the severity of the issue. A "major" violation (also referred to as nonconformance) refers to the inability of a supplier's management system to comply with a core EICC standard. Select major non-conformances can also be denoted as zero tolerance items. Such issues include the utilization of underage child workers, forced labor, health and safety issues posing immediate danger or serious injury, and violation of environmental laws posing serious and immediate harm to the community. "Minor" violations refer to more isolated findings. A temporarily blocked emergency exit or missing safety equipment would be examples of such "minor" violations. Finally, "observations" are generally a recognition that a superior means of documenting or monitoring a process or procedure may exist. Audit items flagged as observations are not considered to be violations of the code of conduct.

\section{Audit Results}

Notwithstanding significant efforts by both HP and the EICC, an analysis of the audit reports reveals persistent problems. As seen in Figure 1, the top seven major code violations comprise three labor-related violations and four environmental, safety and health violations. Nearly $60 \%$ of audited facilities, including those with follow-up or more frequent audits, had routine workweeks longer than 60 hours per week. $40 \%$ of audited plants, including those subjected to follow-up and repeated audits, had no or poor emergency planning, training and evacuation procedures. Finally, 32.5\% of audited firms 
had some troubles with their management of hazardous materials, and $30.2 \%$ had problems with wages and benefits, indicating that wages may not have met local minimums and/or failed to include a premium for overtime work.

--------- Insert Figure 1 about here

When the top four violations are examined by the number of audits conducted at particular plants, whether as follow-up audits or part of a periodic audit process, a clearer picture of persistent trends emerges. Analyzing audit data by number of audits helps explore possible mechanisms that might lead to improvements in audit results, (i.e., increased compliance through more frequent inspections and policing; better working conditions through a plant's enhanced capabilities and management systems). In all cases, we would expect plants to exhibit improvements in their standards as a result of more frequent and numerous factory audits.

Insert Figure 2 about here

However, as seen in Figure 2, while the rate of failed audits in three areas (emergency preparedness, hazardous materials, and wages and benefits) decreased or remained stable between 2004 and 2008, working hour violations occurred at nearly twice the rate as the next most common violation, emergency preparedness $(67 \% \mathrm{vs}$. $35 \%$ ). In short, even with frequent and repeated audits, close to $70 \%$ of HPs suppliers had employees working more than sixty hours per week. Why do working hour violations 
increase even under additional scrutiny and why are they so pervasive? NGO's frequently cite working hour violations as the most highly-significant, recurring problem in these supply chain factories (Good Electronics 2009; Level Works 2006; Verite 2004) confirming what we find in the HP audit data. Likewise, an extraordinary $90 \%$ of EICC members admitted that excessive working hours is an ongoing challenge for them (EICC 2009a). This concern is particularly noteworthy given that the working hours stipulation is the only EICC code item (out of 37 items) that specifically defines the standard: " [...] a workweek should not be more than 60 hours per week, including overtime, except in emergency or unusual situations" (EICC 2009b, 2).

-Insert Figure 3 about here

As seen in Figure 3, an examination of working hour violations by region reveals the most frequent violations, more than $83 \%$, occur in Chinese plants. This is consistent with the literature on Chinese labor issues (Ngai 2005). Plants in Asia-Pacific, primarily Southeast Asia, violate working hours on $34 \%$ of audits. Together these two regions constitute $75 \%$ of HP's total purchases from its external suppliers. In the Asia-Pacific region where purchasing is concentrated, we find violations do not vary significantly in the countries with the largest number of audits conducted: Malaysia, Singapore \& Thailand (36-45\% of audits contain violations) notwithstanding their distinct economic profiles and institutional arrangements. ${ }^{3}$

\footnotetext{
${ }^{3}$ An examination of the audit documents of Malaysian companies revealed that labor violations in Malaysia were underreported. This is due to the auditors' belief that the Malaysian national labor law (which allows 72 hours per week) took precedent over the EICC. The EICC states that working hours shall not exceed 60 hours per week, independent of national laws.
} 
Further highlighting the problems of excessive working hours are data from HP's pilot program of thirteen plants in China, as seen in Figure 4. In January 2008, at the beginning of the HP pilot, 55\% of the workers employed at the thirteen plants participating in the pilot study worked more than the EICC maximum of 60 hours per week. By December 2008, as seasonal demand and orders for new products wound down, only $13 \%$ of these workers were working more than the established limit.. However, in February $2009,50 \%$ of the employees at the pilot study plants were once again working beyond the set limit of 60 hours per week, and by the summer of 2009 , as new product ramp-up accelerated, over $70 \%$ of employees at the thirteen plants were working above the EICC limit.

Insert Figure 4 about here

Interestingly enough, code violations regarding excessive working hours occurred not just in low-wage China, a setting often depicted as not possessing a strong commitment to enforcing labor regulations, but also in Singapore, a high-wage economy characterized by strong institutions, well-trained managers, and more stringent regulatory enforcement.

How Management Policies and Practices Impact Labor Conditions on the Factory Floor

To better understand these patterns of persistent labor standard violations among HP's suppliers, we visited seven first-tier supplier plants across southeast Asia. We were particularly interested in how work was organized and whether such work organization 
influenced outcomes. As seen in Table 2, we purposely chose plants that varied across a number of dimensions. Activities varied from intermediate component manufacture to final assembly: injection molding and hard-disk drive manufacture to wet-cartridge filling and final assembly of ink jet printers. All plants were subsidiaries of publicly traded firms with significant financial resources. Some plants were owned by companies that were affiliated with the EICC, while others were not. Plant output varied from very high (over 90 million units annually) to low (under 2 million units annually). Generally, the higher the annual volume, the lower the mix (variety) of products manufactured in the plant.

Four plants (two in Singapore and two in Thailand) had working hour violations in 2007. Three of these plants were re-audited in 2008 and one again failed to pass the audit. Closer plant-level analysis reveals that all of these violations occurred in plants with high unit volumes and relatively low product mix, plants that leverage economies of scale rather than of scope. For the two plants that passed the second audit, this outcome may have resulted from fortuitous timing rather than actual changes in the nature or organization of work at the two establishments. According to the plant manager, Epsilon, an HDD plant in Thailand, was in the process of being sold to another company and thus a significant amount of work had been transferred internally to another company location $^{4}$. The second plant, Kappa, an injection-molder in Singapore, had also moved a significant amount of work to a new plant in Malaysia ${ }^{5}$. Thus, work hour violations may have decreased not because of changes to management and work practices but simply because a significant amount of work had moved elsewhere. Most importantly, Upsilon,

\footnotetext{
${ }^{4}$ Interview, plant manager, Hard Drive Plant, Thailand 6/17/09

${ }^{5}$ Interview, senior manager. Injection Moulding Plant, Singapore 6/19/09
} 
an ink-jet final assembly plant in Malaysia that chronically violated working hour standards, "passed" the EICC audit because the auditor mistakenly applied Malaysian law which at the time of our research allowed for approximately 74 hours of work per week ${ }^{6}$.

Interviews with managers in five of these seven plants revealed that they believed managing working hour requirements was the most significant challenge they faced. A senior production manager in a hard-disk drive plant in Thailand stated that they had to accommodate a monthly swing in production from 3.8 million units down to 1.3 million and then back up to 2 million. The only way they could do this was by insisting that operators work seven days per week ${ }^{7}$. Consistent with this manager's comments, we found all seven plants employ large numbers of agency or contract workers to help smooth production. These workers, who are overwhelmingly migrants, routinely exceeded $60 \%$ of a plant's total workforce.

--------- Insert Table 2 -------------------

All plants visited for this study use manual labor for final assembly of modules and products, with six out of the seven employing conveyor assembly lines ${ }^{8}$. The six plants with conveyor assembly lines operate with two 12-hour shifts, five to seven days a

\footnotetext{
${ }^{6}$ Malaysian law allowed for 48 hours of straight time per week and 104 hours of overtime per month. The EICC allows for only a total 60 hours per week including overtime. Interview-HR manager, Ink-Jet Assembly Plant, Malaysia 6/24/09

${ }^{7}$ Interview, senior manager-Hard Disk Drive Plant, Thailand 6/17/09

${ }^{8}$ In conveyor or linear assembly, the positions of operators are fixed and assembly occurs in a sequential manner as product travels past these operators on a conveying system.
} 
week, depending upon orders. Managers at all the plants visited in this study claimed that it was often impossible to fulfill orders and meet production schedules by working only five days per week. Each assembly station involved work tasks of between 20 and 30 seconds. Depending upon the sophistication of the product being assembled, assembly lines could grow from 80 to 220 operators, each performing a very narrow task.

Managers at all of these plants were well aware of alternative (cell) assembly options and one plant ran both forms of work organization whenever possible. However, $95 \%$ of employees worked on conveyor assembly lines. Given the reliance on manual labor, one production manager commented that it was difficult to find productivity improvements short of completely automating a line and then that line may not run when volume dropped $^{9}$.

Plant managers claim that they opt for this more Taylorist form of work organization because it permits very short training periods for new operators. These managers indicated that this form of work organization was independent of any specific brand or global lead firm they work with. Managers in almost every plant visited for this study reported that the vast majority of engineers in their plants were process engineers, focused on assembly line efficiencies ${ }^{10}$. Employee turnover at these plants was high and mobility between factories was facilitated by the common work organization of conveyor assembly across all plants, independent of ownership.

\footnotetext{
${ }^{9}$ Interview_production manager, HDD plant, Thailand, 6/17/09

10 Interviews with senior managers, DC Converters, HDD plants_-Thailand 6/15-19/09, Ink Jet FillingSingapore 6/22-23/09, Printer Assembly-Malaysia 6/24/09
} 
Most operators on the assembly lines were female migrant workers ${ }^{11}$ hired on two-year contracts. Most migrant workers sought to maximize their earnings by working overtime whenever possible. Overtime hours were earned after an aggregate total number of hours was achieved ${ }^{12}$, allowing workers to double their wages by working weekends. Because production orders are highly volatile, factories broke their labor contracts with these migrant workers on a regular basis (Good Electronics 2009). The conveyor assembly operations they used allow for both the quick absorption of new workers as well as the ability to rapidly shed these workers when demand suddenly drops.

\section{Explaining Persistent Working Hours Violations: The Cascading Effect of Upstream Business Practices on Labor Standards in the Global Electronics Industry}

\section{The Starting Point: Increasing Industry Dependence on Consumer Markets}

Since the advent of the personal computer, the electronics industry has evolved from being primarily a supplier to governments and large commercial organizations to one whose growth opportunities now originate in consumer markets. Consumer markets are continually subject to cost and product innovation, motivating firms to advance the technological frontier. Increasing consumer technology-adoption rates have also shortened product life cycles.

In order to maximize market share over such short life cycles, retailers engage in constant promotions that rapidly erode selling prices. Given an average product life cycle of 8 months, prices may drop as often as every two months. This price erosion, along

\footnotetext{
${ }^{11}$ Migrant workers in China and Thailand are in-country, while workers in Malaysia and Singapore are foreign.

12 By contrast, this policy differs from those common in advanced industrialized countries where overtime can be achieved by working more than 8 hours any day, independent of aggregate hours.
} 
with the need to carry a broad product assortment, limits retailer appetite for large inventories. Instead retailers opt for more frequent shipments, often by air cargo, to meet consumer demand (Leinbach and Bowen 2004).

This balancing act is complicated by the concentration of electronics retail channels that has occurred in recent years. As seen in Figure 5, the top four competitors in the US consumer electronics and computer retail distribution channels control close to $75 \%$ of their respective markets. Oligopsonistic buying power allows retailers to maintain margins, thus forcing price drops on the brands as the electronics firms move products through their life cycles. Retailers also seek to differentiate product from their competitors in order to prevent consumers from price-shopping products, a process easily facilitated by the Internet.

--------Insert Figure 5 about here--------

As a result, brands often make small functionality changes to products to disguise any potential similarity between rival products. Short product life cycles and the need for thinly differentiated products lead to a constant parade of new product introductions punctuated by rapid phase-outs. For example, in 2009 Hewlett-Packard maintained over 2,000 laser printer product types, more than 15,000 server and storage product types and over eight million possible configure-to-order combinations in its notebook and desktop product lines (Ward et al. 2010). 
How the Electronics Industry Responds to Dynamic Consumer and Retail Markets

The result of these various practices creates great uncertainty within the industry. Buffeted by rapidly changing technology, volatile consumer demand, and powerful retail customers, brands are obligated to optimize supply chain management practices to remain competitive. For example, Kaipia et al looked at the demand and production volatility of a major European electronics manufacturer (Kaipia, Korhonen, and Hartiala 2006). Even with a relatively linear demand, volatility is extreme at the contract manufacturer level with production changes of $80 \%$ on a week-by-week basis.

The electronics industry has sought to manage these supply chain challenges through three broad strategic responses: modular product design, production of buffer inventories of intermediates, and postponement of final assembly until signaled by pullbased ordering systems. Products are designed with standardized, substitutable components that can also be assembled when necessary into common modules. These modules and components, known as intermediates because of their unfinished state, have separate production schedules, allowing for the buildup of buffer inventories that can be easily reallocated among different products at final assembly, depending upon consumer demand. Finally, assembly of finished goods is postponed until accurate demand signals are available. This triggering of orders is known as pull-based ordering due to the dependence on consumer demand (as evidenced by retail point of sales data) for releasing orders into a production system rather than production minimums, as was done during the era of Fordist mass-production. Final products have a significantly higher cost than just the sum of their parts because of the threat of rapid obsolescence. This system works because postponement reduces the financial and reputational risks of unsold finished 
goods inventory.

In order to attenuate volatility during the production of intermediates and encourage the buildup of component inventory, brands choose to take the financial risk of maintaining ownership of and selling components to assemblers on an as needed basis. In a series of articles, scholars working with HP planners laid out the basis for this practice, referred to as "price-masking". Originally conceived as an exercise in bargaining power, the practice has become widespread over time (Ellram and Billington 2001).

On the production side, contract manufacturers are reluctant to absorb inventory risk, unless they have the opportunity to markup components as well as assembly services. Brands, operating under the premise that they only pay for value-add, will not agree to these markups. Instead, they negotiate component pricing directly with the component producer. This policy minimizes inventory risk to the assembler, while allowing the brand to spread its own risk among a portfolio of products. By design, price masking encourages the buildup of buffer inventories at the intermediate stage under the assumption that the financial risk of substitutable components is substantially less than that of finished goods that cannot be reworked.

A byproduct of pull-based systems is that demand volatility is magnified at the final point of assembly. Because brands want to avoid inventory of finished goods and thus postpone final assembly of their products for as long as possible, production volumes exhibit periodic spikes of $300-500 \%$ over baseline levels. This volatility can be further amplified by the timing of frequent new product introductions that require large rampups. The need to plan for this volatility is well known to brands and suppliers and is regularly optimized. HP even publishes demand volatility forecasts and operational 
mitigation techniques in technology operations journals (Burruss and Kuettner 2002).

\section{The Case of Inkjet Printers}

Among the seven plants visited, the Upsilon plant in Malaysia is perhaps the best exemplar of the tensions inherent in manufacturing products for volatile demand markets. It is also the one plant that allowed us to match employee counts with production quantities to better understand the demand uncertainty that is pushed down to suppliers ${ }^{13}$. Upsilon is a vertically integrated producer of inkjet printers that at its historic peak in 2007 produced one million units per month for HP. The plant exhibited the most extreme case of demand volatility among the seven plants visited for this study. It also had a highly developed management program and internal job ladder (for a small group of core workers).

At the time of our research, the plant produced six to eight models per year with an average product life of less than nine months. As seen in Figure 6, monthly volumes could increase by up to $250 \%$. Employment levels could also swing (up and down) by $58 \%$.

To manage its highly volatile production schedules, the Upsilon plant regularly hired $60 \%$ of its workforce through Malaysian government-certified contract agencies. These

\footnotetext{
13 Interviews with senior plant managers and production supervisors-Ink-Jet Final Assembly, Malaysia 6/24/09
} 
agencies recruited Bangladeshi and Nepalese workers who signed two-year contracts with the agency and started work usually in June, in time for the seasonal product rampup. Notwithstanding their two-year employment contract, the plant regularly laid off the vast majority of these workers six months later, due to decreased production orders. Malaysian laws allows for these contracts to be broken as long as workers receive a payment of one month's base wage as severance. Thus, while this process of hiring and firing migrant workers on a regular basis is not a technical violation of the EICC code of conduct, this practice certainly violates the spirit of the code.

Interestingly enough, our interviews at this plant revealed that management tried to be good employers. Both the production facilities and the dormitories housing the migrant workers were modern and in good shape. The plant promoted an extensive Kaizen program. Production supervisors, whenever possible, promoted cell assembly, though this is most often limited to low-volume, high-mix production (less than $5 \%$ of

total production). The issue at this plant was not one of managerial bad will or inadequate management systems but rather of how various upstream business practices constrain production and work organization practices on the shop floor. Given the highly volatile production orders they received, plant managers at Upsilon believed that there was no other way they could profitably run their operations.

Concluding Considerations: Volatility, Production Practices and Labor Standards 
Volatility and its disruptive effects on manufacturing practices and employment relations is not new but rather has a long history in an array of different industries. ${ }^{14}$ But the way that it is being "managed" in today's electronics industry seems to create serious problems for workers. Manufacturing practices in the electronics industry appears to be an odd amalgam of both "lean" and more traditional Taylorist work practices. On the one hand, the industry is characterized by a variety of practices - pull-based ordering, modular design and assembly, price masking, postponement of final assembly - that all appear to enhance efficiencies and mitigate risks for both global brands and their lead suppliers.

On the other hand, these "lean" practices are complemented by an organization of production and work, especially in plants with high volume, low variety production schedules, that appears to be as Taylorist as factories of a by-gone era (McKay 2006; Smith, Sonnenfeld, and Fellow 2006). Pull-based ordering coupled with postponement of final assembly requires that plants have the ability to scale up and down quickly. Automation, while conceptually a possible solution to this volatility, runs the same risk that an earlier era of mass-producers faced: under-utilization of capital-intensive equipment.

Instead, contract manufacturers employ large-scale hand-assembly coupled with lean manufacturing techniques. Operators work on products in a sequential manner with each operation taking 20-30 seconds. Production lines can be added or dropped quickly to meet demand. In this manner, demand/production order volatility is met primarily

\footnotetext{
${ }^{14}$ See (Piore and Sabel 1984) for an historical overview for how both mass production and flexibly specialized firms responded to previous shifts in demand conditions. See (Katz and Sabel 1985) for how volatility was "managed" historically in the US automobile industry.
} 
through the flexible use of labor. Intentionally or unintentionally, Taylorist conveyor assembly is reinforced by the use of price masking policies. While brands may be absorbing contract manufacturers' inventory risk through this practice, they are also taking away opportunities for contract manufacturers to earn additional profit, thus forcing them to maximize labor efficiency as the main way they earn profits (Clark, Kraemer, and Dedrick 2009). This drive to squeeze as much profit out of the work process inevitably leads to an array of different labor standards problems (excessive working hours, low wages, over-reliance on contingent migrant workers, etc.).

Through a case study of Hewlett-Packard and the global electronics industry, we have sought to demonstrate how some persistent labor problems originate in various upstream business practices. Some scholars have argued that as industry dynamics evolve, the governance systems that shape buyer-supplier relations will also change to adapt to more balanced power and/or capabilities between these key players in global supply chains (Gereffi, Humphrey, and Sturgeon 2005). Thus, we might expect that the Taylorist work systems and frequent labor problems described in this article to eventually disappear as supply chain governance becomes more "relational" as opposed to "transactional". This may be possible but in electronics, where brands may control $80 \%$ of the margin (Clark, Kraemer, and Dedrick 2009), their suppliers are not small firms but rather global multinationals with revenue in the billions and operations spread around the world. These contract manufacturers are highly capitalized, publicly-traded firms with deep capabilities. But neither they nor the brands they supply appear able to eradicate persistent labor problems notwithstanding various compliance and/or capability-building efforts. 
Others have argued that the only way to enforce labor standards and improve working conditions, given the absence of a "market for virtue" (Vogel 2005)- that is a business case for resolving these workplace issues - is through greater regulatory enforcement by the state (Reich 2007; Seidman 2007). In a companion paper (Distelhorst, Locke, Pal and Samel 2015) we too illustrate the importance of strong national regulations for enhancing workplace conditions. Yet the Taylorist workplace practices, excessive working hours, and extensive use of migrant labor we describe above are present in both "strong" and "weak" regulatory environments. Interestingly enough, some of these governments (wittingly or unwittingly) have enabled certain exploitative labor practices by promoting policies that protect core workers at the expense of migrant workers who make up the majority of the labor force in the electronics industry.

All of this suggests that if we are serious about improving working conditions and promoting labor rights in global supply chains we need to move beyond our traditional debates over public vs. private regulation and/or particular models of supply chain governance and begin to examine systematically how patterns of consumption impact workplace practices in the factories producing the goods most of us purchase every day. Currently, discussions of ethical consumption focus primarily on the impact various certification schemes may have on the willingness of different types of consumers to pay more or buy more of these supposedly ethically sourced products. We believe that these discussions need to broaden to include policies aimed at shaping consumption patterns that may lead to "fair" prices" for goods produced through "fair" working conditions. In the past, such forms of "regulated competition" existed in which rival firms shifted their competitive strategies away from cut throat pricing and towards more innovation-based 
and sustainable production and distribution practices. Private firms still competed fiercely with one another but the terms of competition were regulated (mostly, self-regulated by the industry associations themselves) in order to protect standards for both firms and their workers. (Berk 1996). Given the growing awareness of and concern for more sustainable business strategies, and the fact that for many of the actors involved in the electronics industry, current practices do not seem to be generating the kinds of high-wage, highskill, high-margin opportunities they had hoped for, perhaps we are at a moment when we could actually begin such a conversation. Whether or not this is possible in today's global economy, and if so, how to structure it, is beyond the scope of this paper but this broader discussion is essential if we are going to promote a more sustainable and just economy. 


\section{REFERENCES}

Amengual, Matthew. 2010. "Complementary Labor Regulation: The Uncoordinated Combination of State and Private Regulators in the Dominican Republic." World Development 38 (3): 405-14.

—. 2014. "Pathways to Enforcement: Labor Inspectors Leveraging Linkages with Society in Argentina." Industrial and Labor Relations Review 67 (1). http://ilr.sagepub.com/content/67/1/3.short.

Bartley, T. 2011. "Transnational Governance as the Layering of Rules: Intersections of Public and Private Standards." Theoretical Inquiries in Law 12 (2): 1-25.

Bartley, Tim, Sebastian Koos, Hiram Samel, Gustavo Setrini, and Nik Summers. 2015. Looking behind the Label: Global Industries and the Conscientious Consumer. Indiana University Press.

Burruss, Jim, and Dorothea Kuettner. 2002. "Forecasting For Short-Lived Products: Hewlett-Packard's Journey." Journal of Business Forecasting Methods and Systems 21 (4): 9-14.

CAFOD. 2004. "Clean Up Your Computer: Working Conditions in the Electronics Sector." London: CAFOD.

Centre for Reflection and Action on Labour Issues (CEREAL). 2007. "Labour Rights in a Time of Crisis."

Chan, Jenny, and Chantal Peyer. 2008. "High Tech - No Rights? One Year Follow Up Report on the Working Conditions in the Electronic Hardware Sector in China." Hong Kong: Students and Scholars Against Corporate Misbeavior (SACOM).

Clark, Gregory, Kenneth L. Kraemer, and Jason Dedrick. 2009. "Who Captures Value in a Global Innovation Network? The Case of Apple's iPod." Communications of the Acm 52 (3): 140-44.

Collins, Jim, and David Packard. 2005. "Foreword to the HP Way." In The HP Way, edited by David Kirby and Karen Lewis, xi - xviii. New York: Harper Collins.

Connor, Tim, and Kelly Dent. 2006. "Offside! Labour Rights and Sportswear Production in Asia." Oxfam. http://www.oxfam.org/en/policy/offside_labor_report.

Coslovsky, S., and R Locke. 2013. "Enforcing Labor Standards in the Sugar Supply Chain: The Brazilian Experience." Politics and Society, Vol. 41, No. 4 (December 2013): 497-526..

Distelhorst, Greg, Jens Hainmueller, and Richard M. Locke. 2016. "Does Lean Improve Labor Standards? Management and Social Performance in the Nike Supply Chain." Management Science, Vol. 63, No. 3 (March 2016): 707-728.

Distelhorst, Greg, Richard M. Locke, Timea Pal, and Hiram Samel. 2015. "Production Goes Global, Compliance Stays Local: Private Regulation in the Global Electronics Industry." Regulation \& Governance 9 (3): 224-42. doi:10.1111/rego.12096.

Duhigg, Charles, and Keith Bradsher. 2012. "Apple, America and a Squeezed Middle Class." The New York Times, January 21, sec. Business Day. http://www.nytimes.com/2012/01/22/business/apple-america-and-a-squeezedmiddle-class.html?hp.

EICC. 2009a. "Electronic Industry Citizenship Coalition: 2008 Annual Report." Electronic Industry Citizenship Coalition. 
- 2009b. "Electronic Industry Code of Conduct: Version 3.01."

Ellram, Lisa, and Corey Billington. 2001. "Purchasing Leverage Considerations in the Outsourcing Decision.” European Journal of Purchasing and Supply Management 7 (1): 15-27.

Fung, Archon, Dara O'Rourke, Charles Sabel, Joshua Cohen, and Rogers. 2001. Can We Put an End to Sweatshops? Boston, Mass.: Beacon Press.

Gereffi, Gary, John Humphrey, and Timothy Sturgeon. 2005. "The Governance of Global Value Chains." Review of International Political Economy 12: 78-104.

Goldthorpe, J. H, D. Lockwood, F. Bechhofer, and J. Platt. 1969. The Affluent Worker in the Class Structure. Cambridge Univ Pr.

Good Electronics. 2009. "Reset: Corporate Social Responsibility in the Global Electronics Supply Chain.” Amsterdam: Good Electronics MVO Platform.

Hainmueller, Jens, Michael Hiscox, and Sandra Sequeira. 2011. "Consumer Demand for the Fair Trade Label: Evidence from a Field Experiment." SSRN eLibrary. http://ssrn.com/paper=1801942.

Interfaith Center on Corporate Responsibility. 2010. "Investor Statement Regarding Suicides and Working Conditions at Electronics Manufacturing Facilities." http://www.iccr.org/news/press_releases/072110InvestorStatementonWorkingCon ditions.pdf.

Jack, Eric P., and Amitabh Raturi. 2002. "Sources of Volume Flexibility and Their Impact on Performance.” Journal of Operations Management 20 (5): 519-48.

Kaipia, Riikka, Hille Korhonen, and Helena Hartiala. 2006. "Planning Nervousness in a Demand Supply Network: An Empirical Study." International Journal of Logistics Management 17 (1): 95-113.

Katz, Harry, and Charles Sabel. 1985. "Industrial Relations \& Industrial Adjustment in the Car Industry." Industrial Relations: A Journal of Economy and Society 24 (3): 295-315.

Kiss, Jemima. 2012. "The Real Price of an iPhone 5: Life in the Foxconn Factory." The Guardian. September 13, 2012. http://www.theguardian.com/technology/2012/sep/13/cost-iphone-5-foxconnfactory.

Leinbach, Thomas R., and John T. Bowen. 2004. "Air Cargo Services and the Electronics Industry in Southeast Asia." Journal of Economic Geography 4 (3): 299-321. doi:10.1093/jnlecg/lbh009.

Level Works. 2006. "Wages, Benefits and Work Hours in the Peoples Reublic of China." San Francisco, CA: Level Works Limited.

Locke, Richard M., Matthew Amengual, and Akshay Mangla. 2009. "Virtue out of Necessity?: Compliance, Commitment and the Improvement of Labor Conditions in Global Supply Chains." Politics \& Society 37: 319-51.

Locke, Richard M., Fei Qin, and Alberto Brause. 2007. "Does Monitoring Improve Labor Standards? Lessons from Nike." Industrial \& Labor Relations Review 61: 3-31.

Locke, Richard M., Ben A. Rissing, and Timea Pal. 2013. "Complements or Substitutes? Private Codes, State Regulation and the Enforcement of Labour Standards in Global Supply Chains.” British Journal of Industrial Relations 51 (3): 519-52.

Locke, Richard M., and Monica Romis. 2007. "Improving Work Conditions in a Global Supply Chain.” MIT Sloan Management Review 48: 54. 
McKay, Steven C. 2006. "Hard Drives and Glass Ceilings - Gender Stratification in High-Tech Production." Gender \& Society 20: 207-35.

Minnich, Dennis, and Frank Maier. 2007. "Responsiveness and Efficiency of Pull-Based and Push-Based Planning Systems in the High-Tech Electronics Industry."

Nadvi, Khalid, and Gale Raj-Reichert. 2015. "Governing Health and Safety at Lower Tiers of the Computer Industry Global Value Chain." Regulation \& Governance 9 (3): 243-58. doi:10.1111/rego.12079.

Nadvi, Khalid, and Frank Waltring. 2004. "Making Sense of Global Standards." In Local Enterprises in the Global Economy: Issues of Governance and Upgrading. Northhampton, MA: Edward Elgar.

Ngai, Pun. 2005. "Global Production, Company Codes of Conduct, and Labor Conditions in China: A Case Study of Two Factories." China Journal 54: 101-13.

O’Rourke, Dara. 2003. "Outsourcing Regulation: Analyzing Nongovernmental Systems of Labor Standards and Monitoring.” Policy Studies Journal 31: 1-29.

Piore, Michael, and Charles Sabel. 1984. The Second Industrial Divide: Possibilities for Prosperity. New York: Basic Books.

Piore, Michael, and Andrew Schrank. 2008. "Toward Managed Flexibility: The Revival of Labour Inspection in the Latin World." International Labour Review 147: 123.

Pruett, Duncan. 2005. "Looking for a Quick Fix: How Weak Social Auditing Is Keeping Workers in Sweatshops." Clean Clothes Campaign.

Reich, Robert. 2007. Supercapitalism: The Transformation of Business, Democracy and Everyday Life. New York: Alfred A. Knopf.

Riisgaard, Lone. 2009. "Global Value Chains, Labor Organization and Private Social Standards: Lessons from East African Cut Flower Industries.” World Development 37: 326-40.

Rodriguez-Garavito, Cesar A. 2005. "Global Governance and Labor Rights: Codes of Conduct and Anti- Sweatshop Struggles in Global Apparel Factories in Mexico and Guatemala." Politics \& Society 33: 203-33.

Rosenzweig, Phillip. 1994. "International Sourcing in Athletic Footwear: Nike and Reebok." Harvard Business School Case.

Rossi, Arianna. 2013. "Does Economic Upgrading Lead to Social Upgrading in Global Production Networks? Evidence from Morocco.” World Development 46: 223-33.

Schrank, Andrew. 2006. "Labor Standards and Human Resources: A Natural Experiment in an Unlikely Laboratory."

Seidman, Gay. 2007. Beyond the Boycott: Labor Rights, Human Rights, and Transnational Activism. New York: Russell Sage Foundation.

Smith, Ted, David Sonnenfeld, and David N. Fellow. 2006. Challenging the Chip : Labor Rights and Environmental Justice in the Global Electronics Industry. Philadelphia: Temple University Press.

Standing, Guy. 2007. "Decent Workplaces, Self-Regulation and CSR: From Puff to Stuff." Working Papers.

Strasser, Julie B., and Laurie Becklund. 1993. Swoosh: The Unauthorized Story of Nike and the Men Who Played There. HarperCollins.

SwedWatch, SACOM, and SOMO. 2008. "Silenced to Deliver: Mobile Phone Manufacturing in China and the Philippines." 
Trumbull, Gunnar. 2006. Consumer Capitalism : Politics, Product Markets and Firm Strategy in France and Germany. Ithaca: Cornell University Press.

Trumbull, Gunnar. 2011. "Consumer Credit in Postwar America and France: The Political Construction of Economic Interests."

Verite. 2004. "Excessive Overtime in Chinese Supplier Factories." Amherst, MA: Verite.

Vogel, David. 2005. The Market for Virtue: The Potential and Limits of Corporate Social Responsibility. Washington D.C.: Brookings Institution Press.

Ward, Julie, Bin Zhang, Shailendra Jain, Chris Fry, Thomas Olavson, Holger Mishal, Jason Amaral, et al. 2010. "HP Transforms Product Portfolio Management with Operations Research." Interfaces 40 (1): 17-32.

Weil, David. 2004. "Public Enforcement/Private Monitoring: Evaluating a New Approach to Regulating the Minimum Wage." Industrial and Labor Relations Review 58 (2): 238-57. 


\section{Tables and Figures}

Table 1: Top Electronics Lead Firms and Contract Manufacturers by Revenue in 2009

\begin{tabular}{|c|c|c|c|c|c|}
\hline Rank & Firm & $\begin{array}{c}2009 \text { Revenue } \\
\text { (Billions) } \\
\end{array}$ & $\begin{array}{c}2009 \text { Net Income } \\
\text { (Billions) }\end{array}$ & $\begin{array}{c}2009 \text { Return } \\
\text { On Sales } \\
\end{array}$ & Employees \\
\hline \multicolumn{6}{|c|}{ Electronics Firms Producing Computer Hardware } \\
\hline 1 & Hewlett Packard & $\$ 114.5$ & $\$ 7.7$ & $6.7 \%$ & 304,000 \\
\hline 2 & IBM & $\$ 95.8$ & $\$ 13.4$ & $14.0 \%$ & 410,830 \\
\hline 3 & Dell & $\$ 61.1$ & $\$ 2.4$ & $3.9 \%$ & 94,300 \\
\hline 4 & Apple & $\$ 42.9$ & $\$ 8.2$ & $19.1 \%$ & 34,300 \\
\hline \multirow[t]{2}{*}{5} & Cisco & $\$ 36.1$ & $\$ 6.1$ & $16.9 \%$ & 65,550 \\
\hline & Total Top 5 & $\$ 350.4$ & $\$ 37.8$ & $10.8 \%$ & 908,980 \\
\hline \multicolumn{6}{|c|}{ Electronics Contract Manufacturers } \\
\hline 1 & Foxconn (Hon Hai) & $\$ 67.8$ & $\$ 2.9$ & $4.3 \%$ & 800,000 \\
\hline 2 & Flextronics & $\$ 30.9$ & $\$(6.1)$ & $-19.7 \%$ & 165,000 \\
\hline 3 & Jabil Circuit & $\$ 11.7$ & $\$(1.1)$ & $-9.4 \%$ & 61,000 \\
\hline 4 & Celestica & $\$ 6.1$ & $\$ 0.1$ & $0.9 \%$ & 25,000 \\
\hline \multirow[t]{2}{*}{5} & Sanmina-SCI & $\$ 5.2$ & $\$(0.1)$ & $-2.6 \%$ & 31,698 \\
\hline & Total Top 5 & $\$ 121.7$ & $\$(4.4)$ & $-3.6 \%$ & $1,082,698$ \\
\hline
\end{tabular}


Figure 1: Largest Code Violations by Total Audit Percentage HP First Tier Suppliers 2004-2008 All Audits*

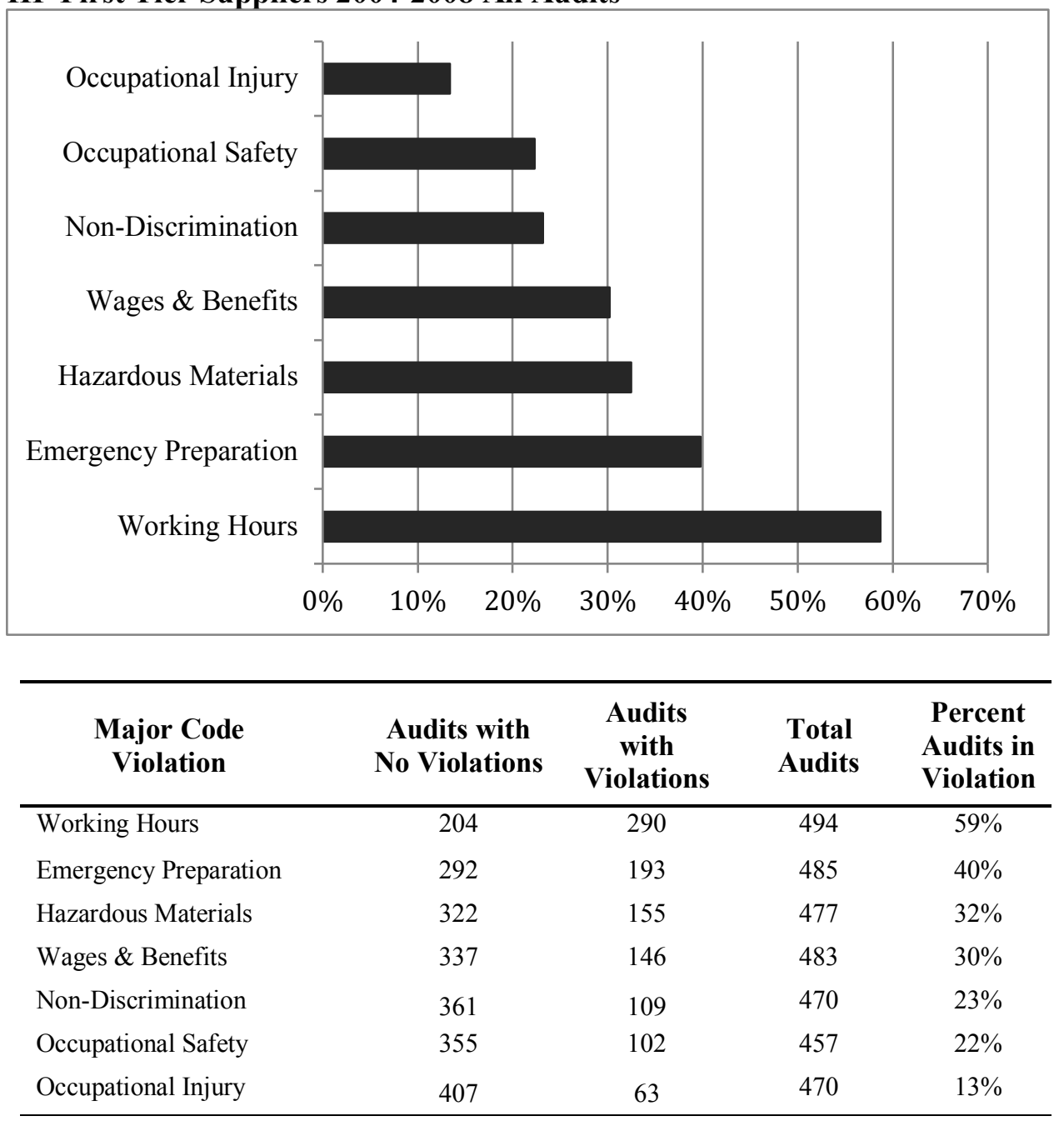

271 Initial Facility Audits, Follow-On Audits Vary as Above 
Figure 2: Largest Code Violations by Audit Number HP First Tier Suppliers 2004-2008 First-Third Audits*

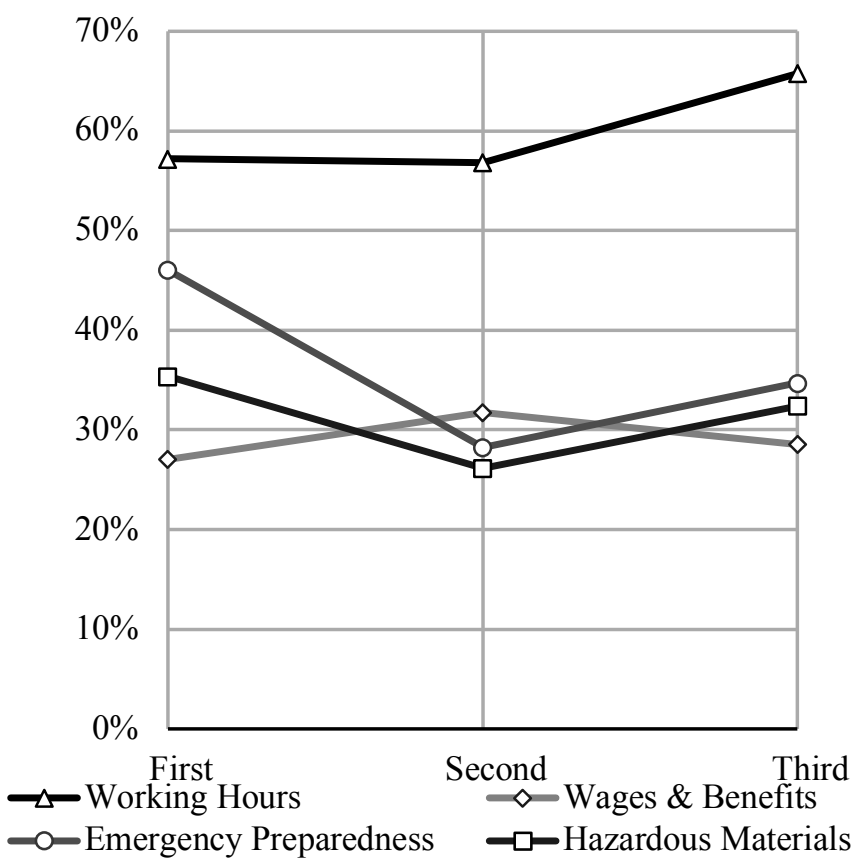

461-476 Audits: 260-271 First Audits, 126-132 Second Audits, 70-73 Third Audits 
Figure 3: Working Hour Violations by Geographic Region HP First Tier Suppliers 2004-2008 All Audits

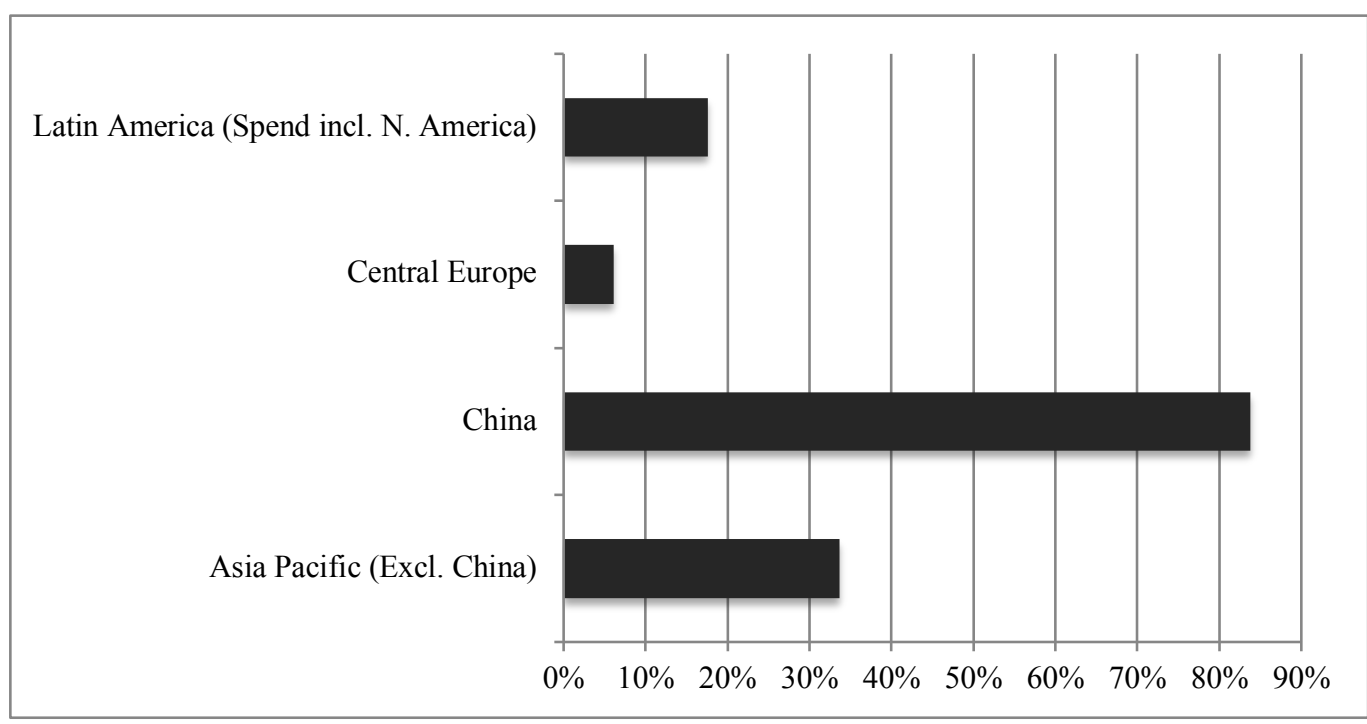

\begin{tabular}{c|ccccc}
\hline $\begin{array}{c}\text { Percent of } \\
\text { Total Annual } \\
\text { HP Spend }\end{array}$ & HP Region & $\begin{array}{c}\text { Audits with } \\
\text { No } \\
\text { Violations }\end{array}$ & $\begin{array}{c}\text { Audits with } \\
\text { Violations }\end{array}$ & $\begin{array}{c}\text { Total } \\
\text { Audits }\end{array}$ & $\begin{array}{c}\text { Percent } \\
\text { of Audits } \\
\text { in } \\
\text { Violation }\end{array}$ \\
\hline $75 \%$ & $\begin{array}{c}\text { Asia Pacific (Excl. } \\
\text { China) } \\
\text { China }\end{array}$ & 63 & 32 & 95 & $34 \%$ \\
\hline $5 \%$ & Central Europe & 46 & 248 & 296 & $84 \%$ \\
\hline $20 \%$ & $\begin{array}{c}\text { Latin America (Spend } \\
\text { incl. N. America) }\end{array}$ & 47 & 10 & 57 & $18 \%$ \\
\hline $100 \%$ & Total & 204 & 293 & 497 & $59 \%$ \\
\hline
\end{tabular}


Figure 4: HP China Supplier Working Hour Study 2008-2009

Percent Direct Labor Working More than 60 Hours per Week

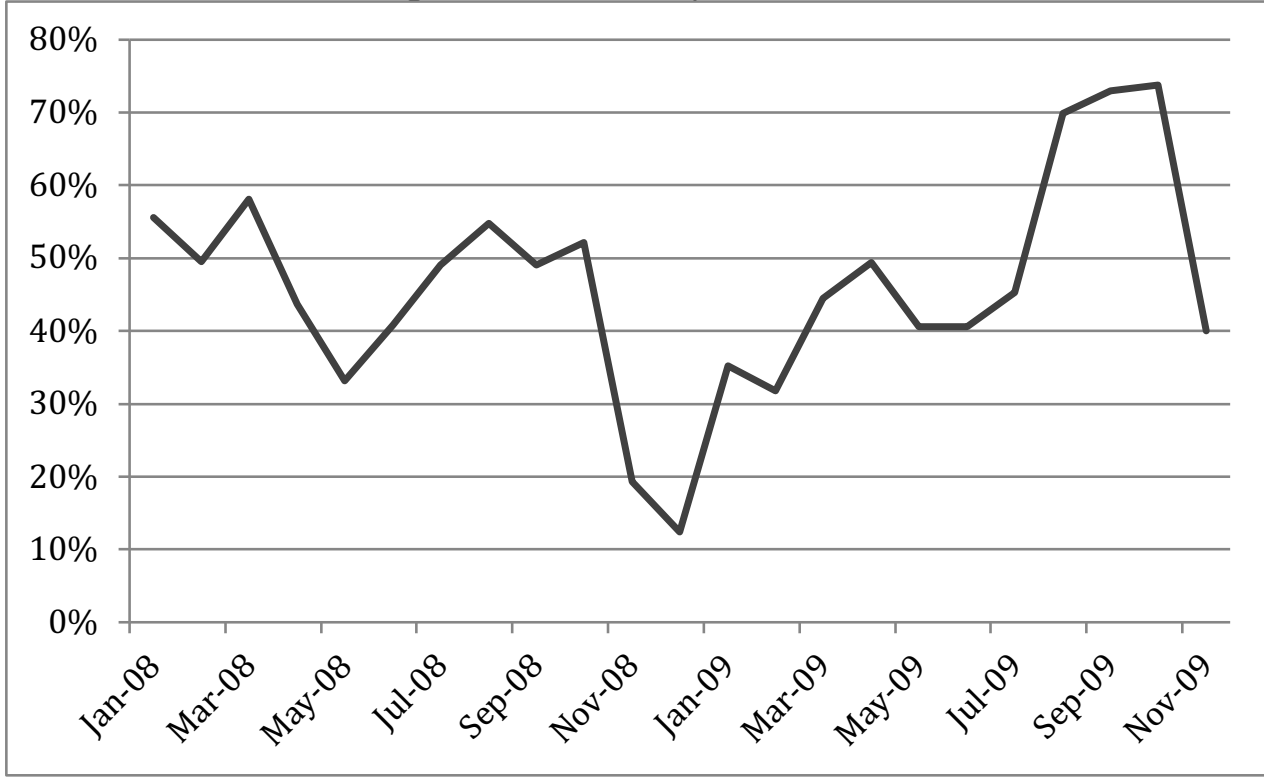

Source: Hewlett-Packard China Working Hours Pilot Program (13 Plants) 
Figure 5: U.S. Electronics Market Concentration by Retail Sector

Major Concentration exists in all sectors except E-Commerce

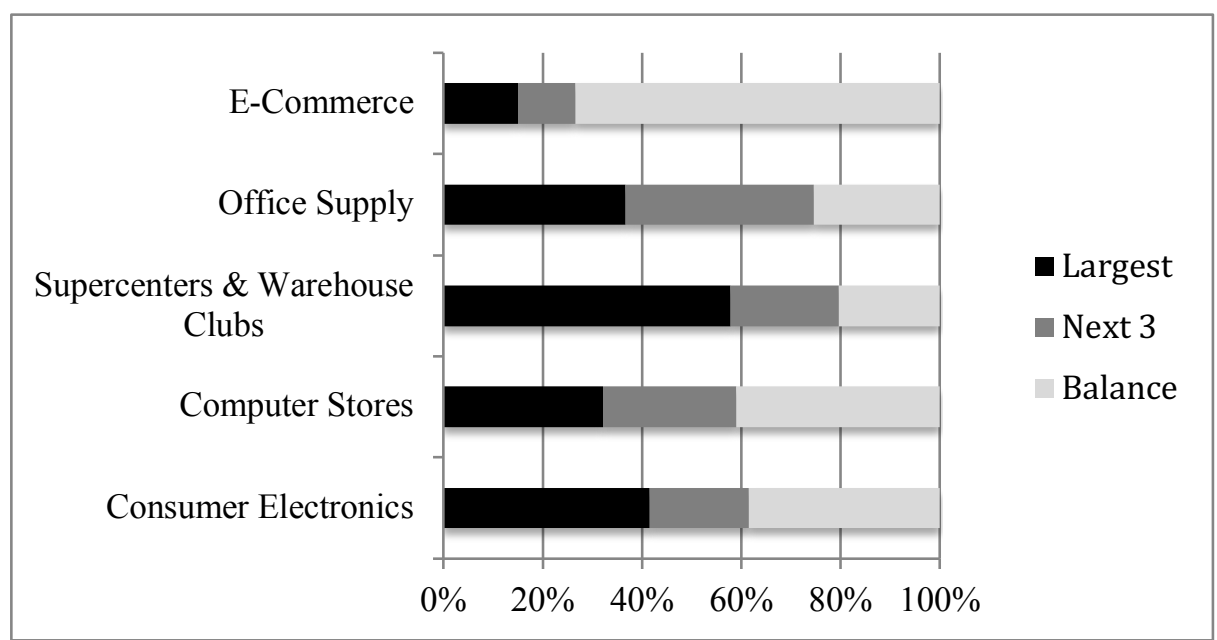

\begin{tabular}{ccccc}
\hline Retail Sector & $\begin{array}{c}\text { Largest } \\
\text { Retailer }\end{array}$ & Largest & Next 3 & Balance \\
\hline Consumer Electronics & Best Buy & $41.5 \%$ & $20.0 \%$ & $38.5 \%$ \\
Computer Stores & Best Buy & $32.2 \%$ & $26.9 \%$ & $40.9 \%$ \\
Supercenters \& Warehouse Clubs & Wal-Mart & $57.9 \%$ & $21.8 \%$ & $20.3 \%$ \\
Office Supply & Staples & $36.7 \%$ & $38.0 \%$ & $25.3 \%$ \\
E-Commerce & Amazon & $15.0 \%$ & $11.7 \%$ & $73.3 \%$ \\
\hline
\end{tabular}

Source: Ibisworld 2010 
Table 2: Product Market Demand Pressure and Work Organization Selection

HP First Tier Supplier Facilities Visited—SE Asia 2009

\begin{tabular}{|c|c|c|c|c|c|c|c|c|}
\hline Company* & & Alpha & Gamma & Epsilon & Kappa & Lambda & Sigma & Upsilon \\
\hline Location & & Thailand & Thailand & Thailand & Singapore & Singapore & Singapore & Malaysia \\
\hline Parent HQ & & Taiwan & US & Japan & Singapore & Canada & US & US \\
\hline $\begin{array}{c}\text { Publicly } \\
\text { Traded } \\
\text { (Exchange) } \\
\end{array}$ & & $\begin{array}{c}\text { Yes } \\
\text { (Bangkok) }\end{array}$ & $\begin{array}{c}\text { Yes } \\
\text { (NYSE) }\end{array}$ & $\begin{array}{c}\text { Yes } \\
\text { (Tokyo) }\end{array}$ & $\begin{array}{c}\text { Yes } \\
\text { (Singapore) }\end{array}$ & $\begin{array}{c}\text { Yes } \\
\text { (NYSE) }\end{array}$ & $\begin{array}{c}\text { Yes } \\
\text { (NASDAQ) }\end{array}$ & $\begin{array}{c}\text { Yes } \\
\text { (NASDAQ) }\end{array}$ \\
\hline $\begin{array}{l}\text { Member } \\
\text { EICC }\end{array}$ & & No & Yes & No & No & Yes & Yes & Yes \\
\hline Product & & $\begin{array}{c}\text { DC-DC } \\
\text { Converters }\end{array}$ & $\begin{array}{l}2.5 " \& 3.5 " \\
\text { Internal HDD }\end{array}$ & $\begin{array}{c}2.5 " \text { Internal } \\
\text { HDD }\end{array}$ & $\begin{array}{l}\text { Mold Making, } \\
\text { Injection } \\
\text { Molding }\end{array}$ & $\begin{array}{c}\text { Inkjet Cartridge } \\
\text { Dry/Wet } \\
\text { Assembly }\end{array}$ & $\begin{array}{c}\text { Rack Mount } \\
\text { Servers }\end{array}$ & $\begin{array}{l}\text { Inkjet \& } \\
\text { Multi- } \\
\text { Function } \\
\text { Printers }\end{array}$ \\
\hline $\begin{array}{c}\text { Intermediate } \\
\text { /Final } \\
\text { Assembly } \\
\end{array}$ & & Intermediate & Intermediate & Intermediate & Intermediate & Final & Final & Final \\
\hline $\begin{array}{l}\text { HP as Total } \\
\% \text { Plant } \\
\text { Production } \\
\end{array}$ & & $5 \%$ & $25 \%$ & $25 \%$ & $50 \%$ & $100 \%$ & $100 \%$ & $95 \%$ \\
\hline \multirow[t]{4}{*}{$\begin{array}{c}\text { Product } \\
\text { Market } \\
\text { Demand } \\
\text { Pressures }\end{array}$} & Demand Volatility & Low & High & High & Medium & Low-Medium & Low & High \\
\hline & $\begin{array}{l}\text { Product Mix } \\
\text { Volume }\end{array}$ & $\begin{array}{l}\text { Low } \\
\text { Medium }\end{array}$ & $\begin{array}{c}\text { Low } \\
\text { High }(>8 \\
\text { million } \\
\text { units monthly) }\end{array}$ & $\begin{array}{c}\text { Low } \\
\text { High }(\sim 3.8 \\
\text { million } \\
\text { units monthly })\end{array}$ & Medium & $\begin{array}{c}\text { Low } \\
\text { High }(>7 \text { million } \\
\text { cartridges } \\
\text { monthly) }\end{array}$ & $\begin{array}{l}\text { High } \\
\text { Low }\end{array}$ & $\begin{array}{l}\text { Low } \\
\text { High }\end{array}$ \\
\hline & Buffer Inventories & No & Yes & Yes & No & No & $\begin{array}{l}\text { Build to } \\
\text { Order }\end{array}$ & No \\
\hline & $\begin{array}{l}\text { HP Use of Price- } \\
\text { Masking } \\
\text { (as \% of Total } \\
\text { Components) }\end{array}$ & Yes (n/a) & No or limited & Yes $(n / a)$ & No & Yes, $(100 \%)$ & Yes $(\sim 80 \%)$ & Yes $(\sim 80 \%)$ \\
\hline \multirow[t]{2}{*}{$\begin{array}{c}\text { Work } \\
\text { Organization } \\
\text { Selection }\end{array}$} & $\begin{array}{c}\text { Production Line } \\
\text { Change } \\
\text { Requires HP Approval }\end{array}$ & $\mathrm{n} / \mathrm{a}$ & No & Yes & Yes & Yes & Yes & Yes \\
\hline & $\begin{array}{c}\text { Type of Assembly } \\
\text { Kaizen/Lean Practices }\end{array}$ & $\begin{array}{l}\text { Conveyor } \\
\text { Yes }\end{array}$ & $\begin{array}{l}\text { Conveyor } \\
\text { Yes }\end{array}$ & $\begin{array}{l}\text { Conveyor } \\
\text { Yes }\end{array}$ & $\begin{array}{l}\text { Cell } \\
\text { Yes }\end{array}$ & $\begin{array}{l}\text { Conveyor } \\
\text { Yes }\end{array}$ & $\begin{array}{l}\text { Cell } \\
\text { Yes }\end{array}$ & $\begin{array}{l}\text { Conveyor } \\
\text { Yes }\end{array}$ \\
\hline
\end{tabular}




\begin{tabular}{|c|c|c|c|c|c|c|c|}
\hline \\
\hline $\begin{array}{l}\text { Plant Employees } \\
2008\end{array}$ & 8,800 & 28,000 & 8,500 & 570 & 550 & 297 & 12,000 \\
\hline Union & $\begin{array}{l}\text { Company } \\
\text { union }\end{array}$ & $\begin{array}{c}\text { No, uses } \\
\text { strategic HR }\end{array}$ & $\begin{array}{c}\text { None, } \\
\text { Welfare } \\
\text { Committee }\end{array}$ & $\begin{array}{l}\text { Branch of } \\
\text { National } \\
\text { Union }\end{array}$ & $\begin{array}{l}\text { Branch of } \\
\text { National } \\
\text { Union }\end{array}$ & $\begin{array}{l}\text { Branch of } \\
\text { National } \\
\text { Union }\end{array}$ & No \\
\hline $\begin{array}{l}\text { Use of Contract } \\
\text { Workers }\end{array}$ & $\begin{array}{l}\text { Phased out } \\
2005\end{array}$ & $\begin{array}{c}\text { Was } 70 \% \text { until } \\
2008\end{array}$ & $\begin{array}{c}77 \% \text { of } \\
\text { employees }\end{array}$ & $\begin{array}{c}45 \% \text { of total at } \\
\text { lower wages }\end{array}$ & $\begin{array}{l}55 \% \text { of total at } \\
\text { lower wages }\end{array}$ & $\begin{array}{c}20-30 \% \text { of } \\
\text { total at } \\
\text { lower wages }\end{array}$ & $>60 \%$ \\
\hline $\begin{array}{c}\% \text { of Total } \\
\text { Employees/ } \\
\text { Contract Workers that } \\
\text { are } \\
\text { Migrant }\end{array}$ & less than $5 \%$ & $\begin{array}{c}\text { greater than } \\
50 \% \\
\text { (in-country: } \\
\text { Isan) }\end{array}$ & $\begin{array}{l}\text { greater than } 50 \% \\
\text { (in-country: Isan) }\end{array}$ & $\begin{array}{c}45 \% \\
\text { (mainly Malay } \\
\text { and Chinese) }\end{array}$ & $\begin{array}{l}\sim 60 \% \text { (mainly } \\
\text { Malay) }\end{array}$ & $20-30 \%$ & $\begin{array}{c}>50 \% \\
\text { (Bangladeshi, } \\
\text { Nepali) }\end{array}$ \\
\hline $\begin{array}{l}\text { Women as \% of } \\
\text { Total Employees }\end{array}$ & $84 \%$ & $85-90 \%$ & $85 \%$ & $\mathrm{n} / \mathrm{a}$ & $85 \%$ & $\mathrm{n} / \mathrm{a}$ & $55 \%$ \\
\hline \multirow[t]{2}{*}{$\begin{array}{l}\text { Working Hours Audit } \\
\text { Results }\end{array}$} & $\begin{array}{c}\text { No } \\
\text { Violation }\end{array}$ & 2007-Yes & 2007-Yes & 2007-Yes & 2007-Yes & $\begin{array}{c}\text { No } \\
\text { Violation }\end{array}$ & No Violation \\
\hline & & 2008-Yes & 2008-No & 2008-No & & & \\
\hline $\begin{array}{c}\text { Number of Shifts } \\
\text { Per Day }\end{array}$ & $\begin{array}{l}2-12 \mathrm{hr} . \\
\text { (5 days on, } \\
2 \text { off) }\end{array}$ & $\begin{array}{c}3-8 \mathrm{hr} \\
\text { (6 days on, } 1 \\
\text { off) }\end{array}$ & $\begin{array}{c}2-12 \mathrm{hr} . \\
\text { (5 days on, } 2 \text { off) }\end{array}$ & $\begin{array}{c}2-12 \mathrm{hr} . \\
\text { (5 days on, } 2 \\
\text { off) }\end{array}$ & $\begin{array}{c}4-12 \mathrm{hr} . \\
\text { (4 days on, } 3 \text { off) }\end{array}$ & $\begin{array}{c}3-8 \mathrm{hr} \\
\text { (5 days on, } \\
2 \text { off) }\end{array}$ & $\begin{array}{c}2-12 \mathrm{hr} \\
\text { (5 days on, } 2 \\
\text { off) }\end{array}$ \\
\hline
\end{tabular}


Figure 6: Ink Jet Shipments (All Products)—Upsilon Plant 2008-2009 Average Product Cycle-9 months, 6-8 models

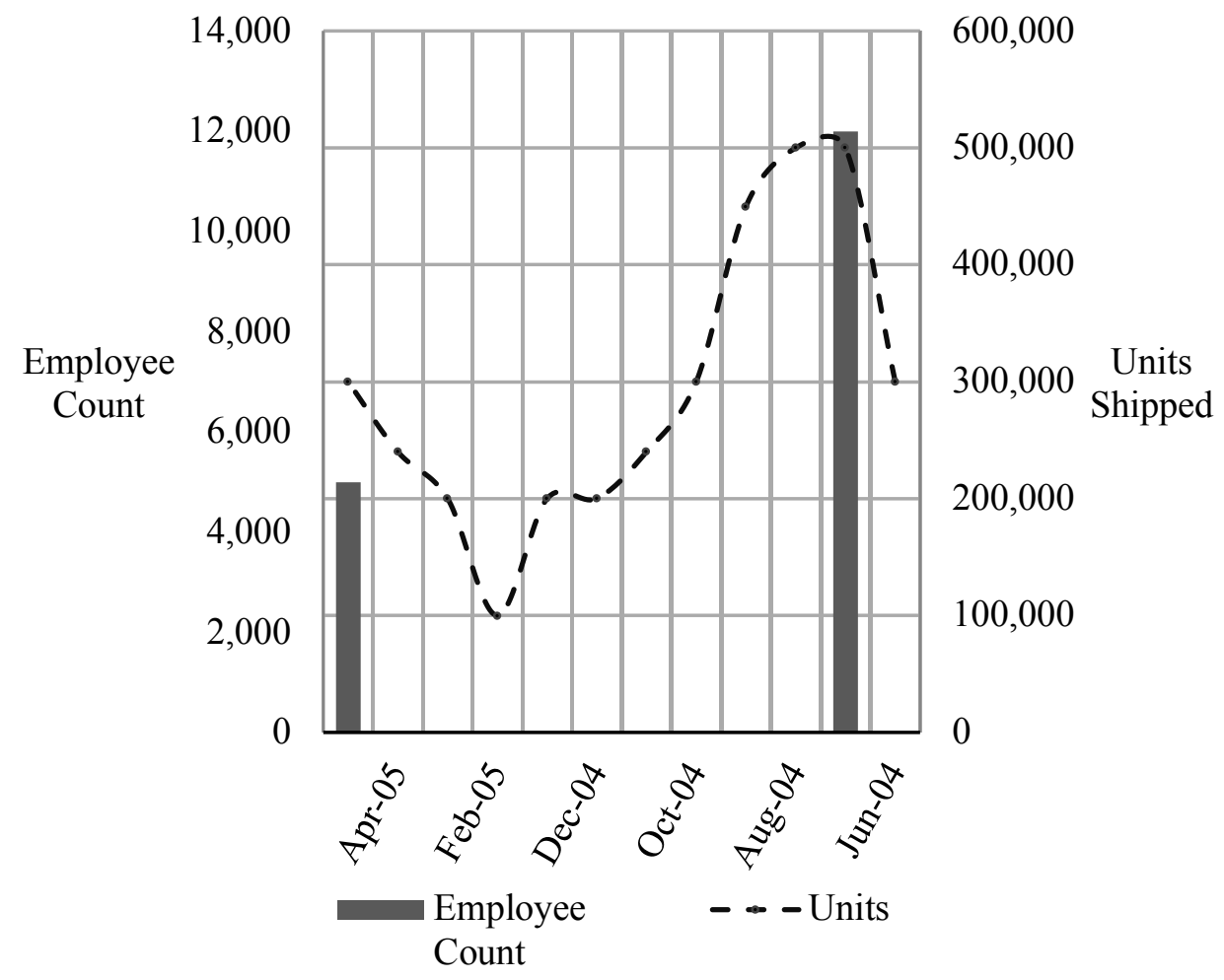

